\title{
New Concepts on the Development of East Brazilian Marginal Basins
}

\author{
by Hung K. Chang, Renato O. Kowsmann and Antonio M.F. de Figueiredo
}

One obvious focus in recent years for Brazilian geology has been the marginal basins of the eastern part of the country, which now produce $70 \%$ of Brazil's oil. Indeed this region is now regarded as a classic Atlantic-type margin. The authors review here recent seismic data and basin models, which enable a reconstruction of the Jurassic-Cretaceous stratigraphy and its relationship to the evolution of the Atlantic Ocean. (Ed.)

\section{Introduction}

The continental margin of Eastern Brazil comprises six riftinitiated basins (Sergipe-Alagoas, Bahia Sul, Espirito Santo, Campos, Santos and Pelotas), which occupy the coastal plain, continental shelf and slope of the western portion of the South Atlantic Ocean (Fig. 1). Since the late 1960s, when offshore exploration for hydrocarbons began, a large amount of geological and geophysical data has been obtained on these basins.

Two major developments have helped to increase our knowledge of the origin and development of these basins in recent years (see Ponte and Asmus, 1978; Ojeda, 1982, and Asmus and Baisch, 1983, for general reviews). One is the consider-

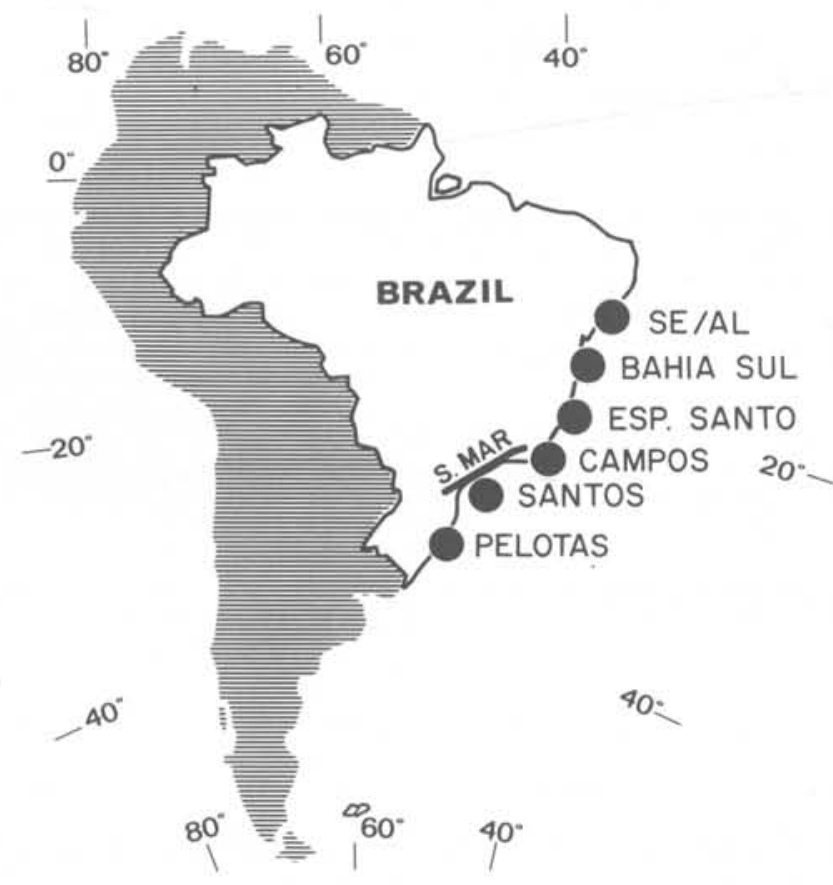

Figure 1: Location of the East Brazil marginal basins. S. Mar: Serra do Mar coastal range.

SE/A1: Sergipe/Alagoas Basin. ESP. SANTO: Espírito Santo Basin. able improvements in the acquisition of data (especially seismic) along the marginal basins. The other is the development of conceptual models for the thermo-mechanical behaviour of sedimentary basins and the recognition of global variations in Mesozoic-Cenozoic sea levels.

The general Jurassic to Cretaceous stratigraphy of the eastern Brazil offshore basins (Fig. 2) can be represented by five megasequences: continental, transitional evaporitic, shallow carbonate platform, marine transgressive and marine regressive (Ponte et al., 1978). These megasequences are linked to the continental breakup of the Pangea and to the evolution of the Atlantic Ocean.

\section{The Continental Megasequence}

Three synrift sequences comprise the continental megasequence, based on their characteristic facies associations (Fig. 3) and structural styles, and following a scheme used by Figueiredo (1981). The first sequence (Syn-Rift I) is hardly affected by faulting, whereas the other two (Syn-Rift II and III) are subject to intense faulting.

Syn-rift I. During the latest Jurassic (Dom João or Volgian Stage, see Figure 2, two areas became separate as a consequence of the initial process of Gondwanaland breakup. To the north of the Espírito Santo Basin, a huge depression formed, known as the "African-Brazilian Depression" (Ponte et al., 1971). This was rapidly filled with a complex package of arid alluvial fans and by coarse-grained fluvial deposits with subordinate evaporites, representing local playa-lake environments. Eolian deposits are also common in this sequence. To the south data are lacking, but the sequence here is thought to be composed of the same sedimentary sequence present to the north or volcanics, or both, as in the lower Congo River Basin of Zaire (R. Palagi, personal communication).

Syn-rift II: The inception of the main rift phase, in the Early Cretaceous (Rio da Serra-Aratu or Neocomian stages), generated a series of a rapidly subsiding half-grabens along the entire margin. To the north, a series of deep and stratified lakes formed and filled with dark-coloured organic-rich shales and by turbidites associated with fluvial-deltaic clastics. Subordinate ostracodal calcarenites are related to episodic flooding.

To the south, however, volcanism was very active (Fig. 3). The volcanic-sedimentary sequence is best studied in the Campos Basin, where it is composed of basalt flows, volcaniclastics and sedimentary rocks with ages ranging from 120 to $130 \mathrm{Ma}$ (Mizusaki, 1986; Ponte and Asmus, 1978). Mizusaki recognizes areas with subaqueous, lacustrine and subaereal volcanism, the latter characterized by explosive episodes.

Later, lakes became progressively shallower and voleanic events less marked. Shallow lakes to the north were slowly filled by very extensive, cyclic fluvial-deltaic clastics con- 


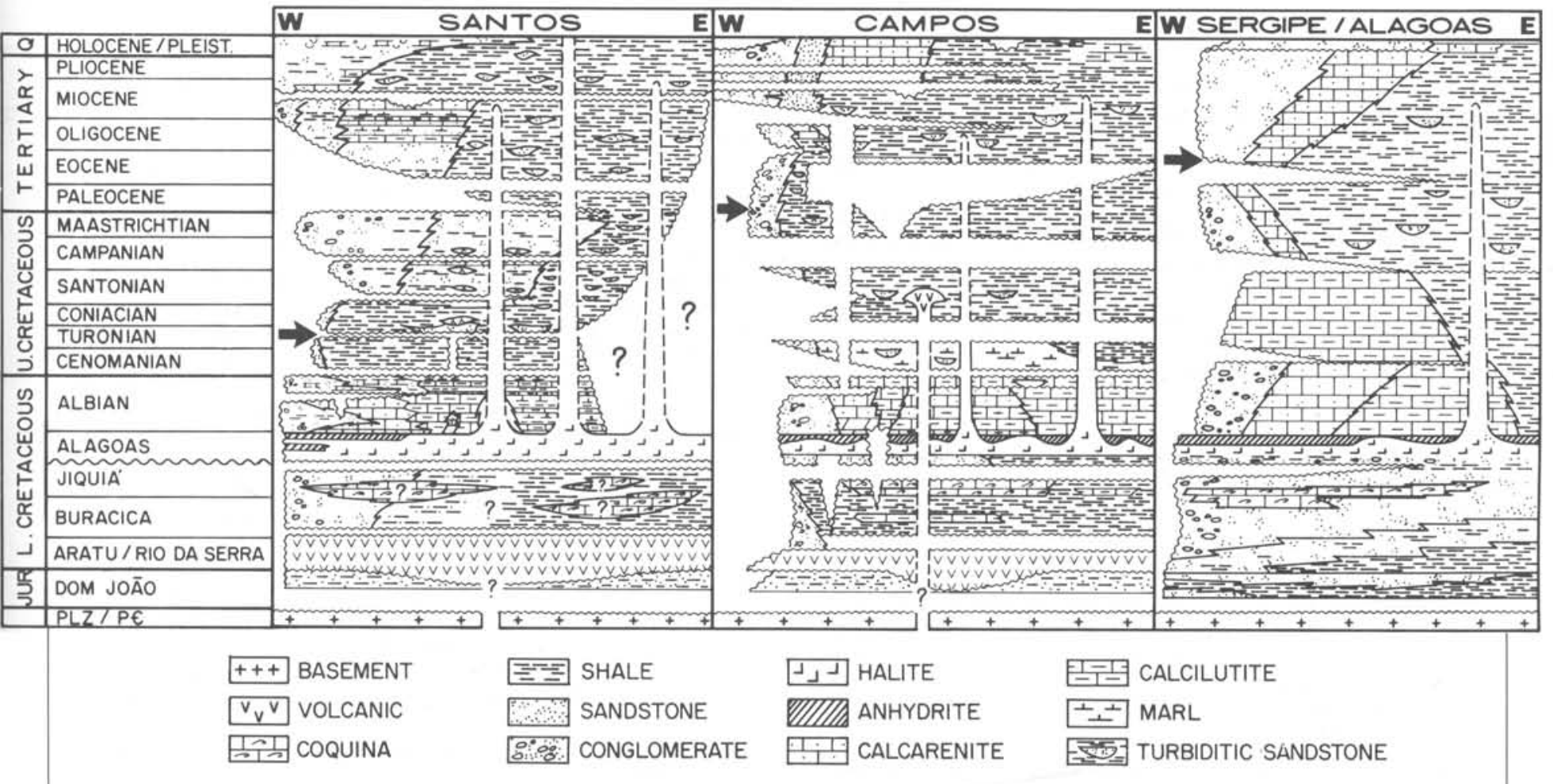

Figure 2: Stratigraphic chart of three representative marginal basins of East Brazil. Arrows mark transition between Marine Transgressive and Marine Regressive megasequences.

trolled by rapid base-level changes in response to climatic variations. To the south, sedimentation was characterized by fine-grained lacustrine rocks associated with volcaniclastics. In this region alkaline and saline lakes dominated, as demonstrated by the presence of thick oolitic talcstevensite rocks (Rehim et al., 1986).

Syn-rift III: This sequence, deposited during the BuracicaJiquia (Barremian) stages, is characterized by the presence of very extensive and laterally continuous beds of coquinas, intercalated with coarse to fine-grained siliciclastic material (Fig. 3). The coquinas are formed by calcarenites and calcirudites composed of ostracods, pelecypods, and some gastropods.

For the Campos Basin, Bertani and Carozzi (1984) interpreted the coquina-clastic sequence in terms of playa-lake and pluvial-lake environments, associated with cyclic expansions and contractions of the lakes. In the playa-lake environment, coarse clastics (alluvial fans) graded into sand and mud flats. In the lowlands, carbonate flats were developed adjacent to saline lakes, where matrix-supported ostracodal biocalcarenites were deposited, and in the centers of the lakes euxinic shales were formed. The pluvial-lake environment was active during flooding events, when grain-supported pelecypod biocalcarenites covered very large areas of the basin.

In the Sergipe-Alagoas Basin (Figueiredo, 1981) this sequence is represented by mixed clastic-carbonate sedimentation. Large pelecypod-carbonate banks deposited in very shallow areas flank the principal point-sources (rivers) responsible for the deposition of fan-delta, fluvial-deltaic and slope-basin terrigenous sediments. At the end of this sequence the clastic sedimentation prograded across the entire basin and buried the carbonate banks.

The evolutionary pattern of the continental megasequence resembles that of the East African Rift as proposed by Le Fournier and others (1985), despite the differences in the duration of rifting. There is an excellent agreement between the sequence subdivisions (Syn-Rift I, II, III) and stages $1,3 a$, and $3 b$ of these workers.

\section{The Transitional Evaporitic Megasequence}

This megasequence, deposited during the Alagoas (Aptian) Stage, is composed of sediments typical of the transition between continent and marine environments. It was deposited over a widespread post-rift unconformity (Fig. 2) responsible for the general peneplanation of the rift topography. In places this flat-lying surface was cover?d by a relatively thin, coarse clastic wedge derived from the adjacent highlands, but it was gradually inundated by salty water coming from the ocean to the south. Conglomerates and poorly sorted sandstones were deposited and gradually overlain by fine-grained clastics and euxinic, saline, organic-rich shales.

A narrow evaporitic seaway formed along the entire East Brazilian margin north of Pelotas Basin and resulted in the deposition of a complete suite of evaporites (Figs. 2, 3). The original salt thickness is estimated to be about $2000 \mathrm{~m}$ in the depocenters of this saline gulf.

This evaporitic section has been well studied by Szatmari and others (1979) in the Sergipe-Alagoas Basin. Two distinet periods of evaporite sedimentation in a very shallow environment - progressive and recessive - were recognized, associated with a gradual increase in salinity followed by an initially abrupt and then gradual dilution of the brines. The sediments of these two cycles provide evidence of several other less dominant cycles reflecting changes in salinity and detrital content. In successive order of formation the dominant components are anhydrite, halite, carnalite and finally tachyhydrite. Silvinite and halite are the major components of the recessive suite.

In other basins the evaporite sequence is poorly known, but there is good evidence for the existence of highly soluble salts. The control and distribution of these suites are not well understood, but the massive salt deposits located in distal portions of the margin are probably halite.

\section{The Shallow Carbonate Platform Megasequence}

During the Albian Stage, the gradual opening of the incipient seaway resulted in the Alagoas evaporites being succeeded by an extensive high-energy carbonate platform (Fig. 3) composed of shallow-water limestones consisting of four main components: oncolites, pellets, oolites and bioclasts. The latter are the least important and reflect the restricted saline conditions still present in these waters. 
Along the ancient Albian coastline, fan-delta clastic systems were also developed and intermixed with the carbonate rocks. Dolomitized limestones are rather abundant in the basal part of the platform, but rigid framework structures such as reefs are absent. In basinal areas calcilutites and calcisiltites intercalated with marls and shales are the dominant facies. The depositional model developed for this sequence is a typical carbonate ramp disturbed by salt tectonics (Spadini et al., in press) that controlled the shallow-water carbonate facies distribution, and especially the oncolite-oolite shoals.

Marine Transgressive Megasequence

In the late Albian the high-energy carbonate sequence was followed by a low-energy sequence composed of ealcilutites, marls and shales. These were deposited in a gradually deepening environment (deep neritic to upper bathyal) as indicated by the paleoecological studies of Dias-Brito (1982) and Koutsoukos and Dias-Brito (1987). The calcilutites are massive and rhythmically bedded with marls and shales towards the top of the sequence. Planktonic foraminifers and calcispheres are abundant, with minor benthic foraminifers, carbonacous fragments and micas. An important Cenomanian-Turonian anoxic event was registered when the basin depth reached $200-300 \mathrm{~m}$. Radiolarians and planktonic foraminifera are abundant and highly diversified (Azevedo et al., 1987).

Turbidite sedimentation is present along the entire margin, and is best studied in the Campos Basin. Two models of deep-water turbiditic sedimentation have been identified blanket and channelized systems. The former is associated with Albian marls and is characterized by the presence of very continuous sandstone bodies covering as much as 200 $\mathrm{km}^{2}$. The channelized system is confined in depressions produced by halokinesis within the Cenomanian-Turonian shales and is characterized by rapid variations in both facies and thickness.

The Marine Regressive Megasequence

This sequence is composed of a set of synchronous depositional systems (fan delta, fluvial-deltaic, terrigenous shelf, carbonate platform, slope and basin) seismically characterized by an offlap pattern underneath the present continental shelf. In some areas this progradational pattern is replaced by an aggradational build-up of a high-energy carbonate platform. The passage from the transgressive to regressive sequence varies in age along the margin (see Fig. 2).

In the southern area siliciclastic systems dominate, whereas in the northern area platform carbonates are well developed. Deep-water systems also reflect this difference: the Campos Basin contains very large turbidite sand bodies, whereas those in Sergipe-Alagoas are sand poor.

In the Campos Basin, the major occurrences of large unconfined deep-water sand bodies are associated with relative sea-level falls. During these periods the exposure of the siliciclastic-rich continental shelf resulted in the introduction of huge amounts of sand into the deep basin. Turbiditic fans as large as $300 \mathrm{~km}^{2}$ were deposited and seismic data suggest the presence of even larger fans under the present continental slope. Salt movements in some areas have strongly affected the geometry and distribution of these deep-water sand bodies.

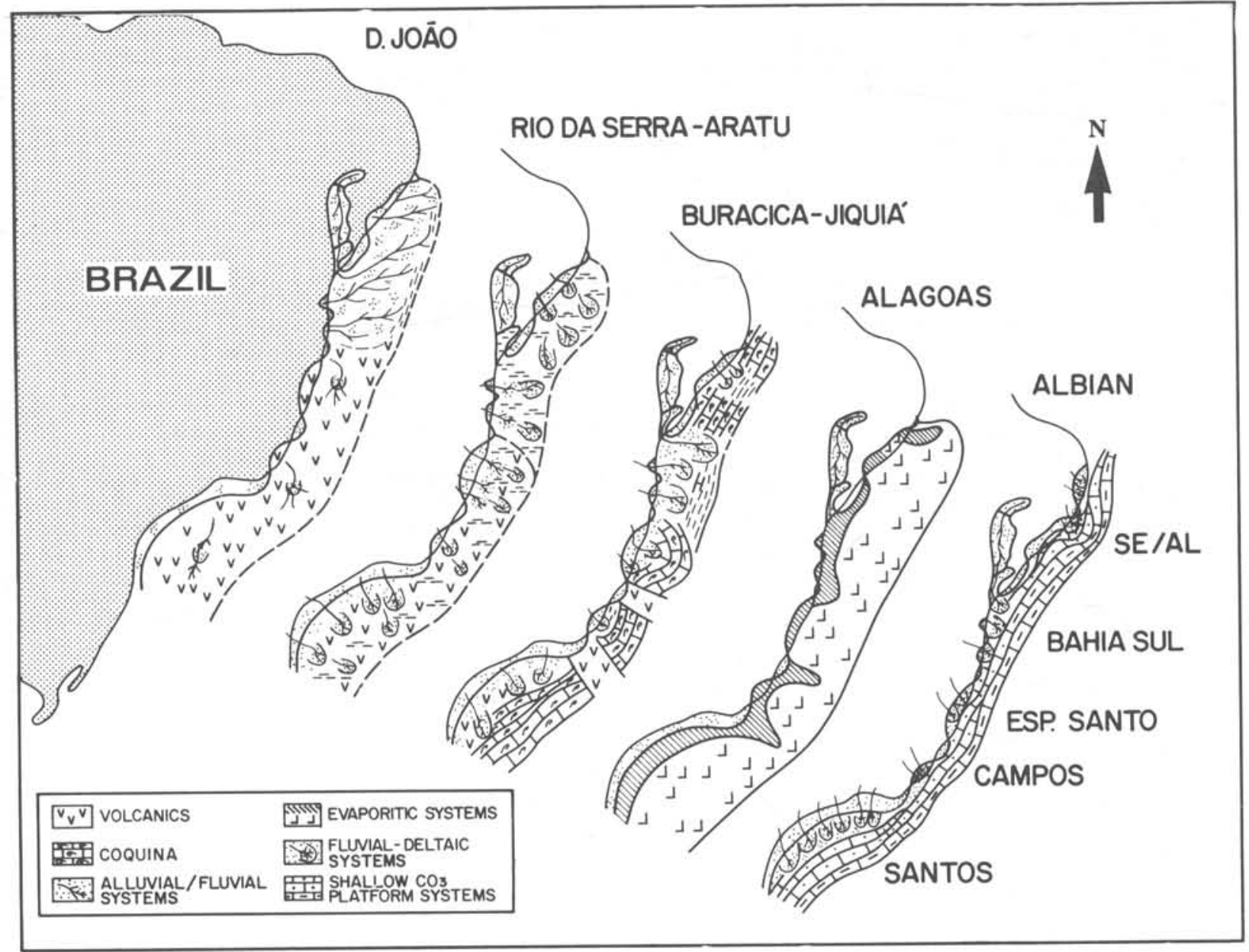

Figure 3: Paleogeographic reconstructions for the Syn-Rift sequences I (Dom João), II (Rio da SerraAratu), III (Buracica/Jiquiá), and the Transitional Evaporitic (Alagoas) and Shallow Carbonate Platform (Albian) megasequences. 


\section{Tectonic Setting}

Many plate tectonic reconstructions of the early South Atlantic have been proposed since the famous 1965 fit by Bullard and his colleagues. Early models matched coastline shapes or adjacent isobaths and moved the continental masses of South America and Africa along fracture zone flow lines, thus determining early poles of rotation. A much more sophisticated reconstruction, involving plate kinematics was presented by Rabinowitz and LaBrecque (1979), based on the identification of M-series magnetic anomalies to the south of the Walvis-São Paulo ridges. The continents were moved apart as single rigid blocks according to the location and ages of the anomalies. The large gap covered by evaporites to the north of the ridges was assumed to be formed by oceanic crust (Cande and Rabinowitz, 1978).

The realization by Austin and Uchupi (1982), based on seismic reflection data, that most of the $M$ anomalies occurred over thinned continental crust altered these reconstructions considerably. According to them, sea-floor spreading in the South Atlantic was initiated much later than previously believed, around anomaly M4 time (Hauterivian - $125 \mathrm{Ma}$ ago). North of the Walvis-São Paulo ridges oceanic crust was emplaced near the Aptian-Albian boundary $113 \mathrm{Ma}$ ago, after evaporite deposition over stretched continental crust.

The strong contrast in both oceanic and thinned continental crust between segments north and south of the Walvis-São Paulo ridges is due to a large shear zone (Curie, 1984). Although the exact location and time of initiation of this proposed shear zone is still under debate, it introduced the important notion that the South American plate may not have been so rigid after all. Vink (1982) proposed a propagating rift mechanism for the continental splitting of South America and Africa. His model was corroborated by Szatmari and others (1985), in their study of structural evidence in the rift sequence of the Brazilian marginal basins.

The Brazilian marginal basins were first introduced into the plate tectonic context by Estrella (1972) and Asmus and Porto (1972). Later Asmus and Ponte (1973) and Ponte and Asmus (1978) subdivided basin evolution into four tectonic stages: pre-rift, rift valley, proto-oceanic, and continental margin. Genetic interpretation of the early stages of basin development (Asmus and Porto, 1980) were inspired by the models of Sleep (1971) and Milanovsky (1972). The East Brazilian margin was grouped into two rifting styles, domic (Santos and Campos basins) and interdomic (Bahia Sul and Sergipe-Alagoas basins), according to the presence of volcanism and the absence of pre-rift sediments. These styles can be basically translated into active and passive rifting, respectively.

The power and conceptual elegance of McKenzie's (1978) model of lithospheric stretching proved to be very useful in explaining the development of the East Brazilian marginal basins, as in other passive margins of the world. Applications of the model in the Santos and Sergipe-Alagoas basins (Chang and Kowsmann, 1984, 1986) and the Campos Basin (Mohriak and Dewey, 1987) confirmed that uniform and non-uniform stretching of the lithosphere together with two-stage basin subsidence (mechanical rifting followed by thermal contraction) amplified by flexural loading of sediments account for the evolutionary pattern of these basins (Fig. 4). Alternative models involving simple-shear (Wernicke, 1985) inspired subsequent proposals for basin development along the Northeast Brazil margin (Ussami et al., 1986; Castro, 1987). Although there is a great volume of data on the East Brazil basins, this is still insufficient in depth of penetration to confirm any of these models.

An indisputable fact is that the composition and structural fabric of the underlying Precambrian basement exerted a strong control in basin emplacement and evolution (Cordani et al., 1984). Cratonic shield areas, adjacent polycyclic mobile belts and suture zones separating crustal blocks of different rheological behaviour determined the location of the border faults of the basins and of the neighbouring highs that separate them. These provinces also exerted controls on the limits of the compartments subject to differential crustal stretching; they also determined the orientation of the structures within the basins.
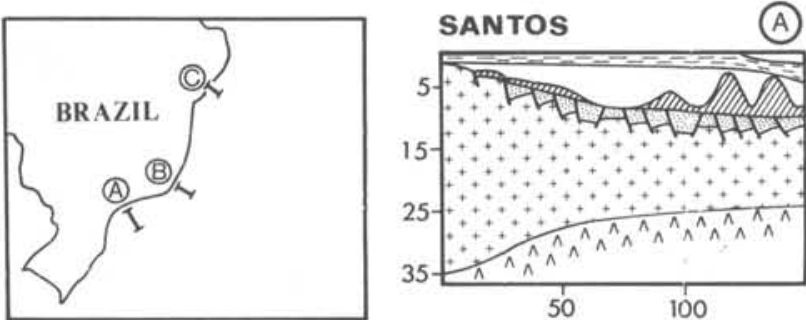

CAMPOS
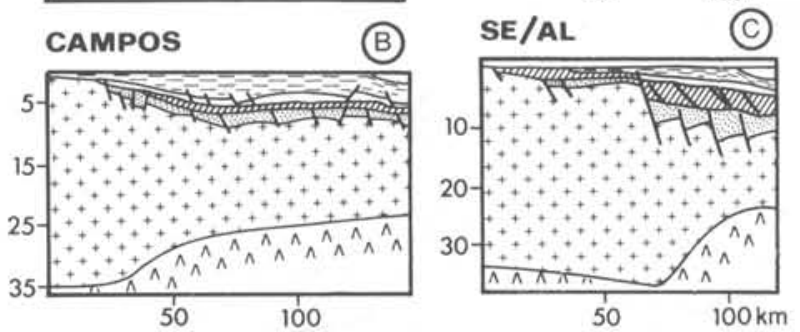

Figure 4: Crustal structure based on tectonic subsidence and gravity modelling. Upper mantle (V); continental crust (crosses); Rift Stage Continental Megasequence (dotted); Post-Rift Stage megasequences: Transitional Evaporitic (hachured), Shallow Carbonate Platform and Marine Transgressive (blank), Marine Regressive (dashed).

\section{The Rift Stage}

Gravity and tectonic subsidence modelling along the East Brazilian margin suggests that individual basins were subject to different amounts of stretching. These differences were taken-up by transfer zones, which are expressed by significant apparent offsets in the trace of basin hinge zones. The latter separate unstretched from stretched continental crust and are recognized by accentuated deepening of basement and shallowing of the Moho discontinuity. The transfer zones usually extend offshore as oceanic fracture zones, and the most conspicuous of the former occur in the south, between the Pelotas, Santos and Campos basins (Fig. 5). The Pelotas-Santos transfer zone is marked by the Florianópolis High-São Paulo Ridge complex, which acted as the southernmost barrier to Alagoas (Aptian) evaporite deposition. The transfer zone between Campos and Santos basins is delineated by a very conspicuous east-west trend of the hinge zone adjacent to the Rio de Janeiro Fracture Zone, which terminates against the Cabo Frio High.

Continental stretching in the region of the Pelotas Basin probably started in the Middle to Late Jurassic. Only the top of the rift sequence composed of seaward dipping basalt flows (Fontana, 1987) has been dated, with $\mathrm{K}-\mathrm{Ar}$ ages approximating $120 \mathrm{Ma}$. Stretching to the north of the Florianópolis High-São Paulo Ridge probably started somewhat later, during the Dom João Stage (Syn-Rift I). The Reconcavo-Tucano Aulacogen and the onshore portion of the Sergipe-Alagoas Basin contain the best developed section of Rio da Serra-Aratu rift sequence (Syn-Rift II), probably because of the rotation of regional continental blocks that preceded the main event of rifting along the adjacent margin (Lana and Milani, 1986).

In the Santos and Campos basins, these basal rift sediments (Syn-Rift II) have not been recovered and may be dominated by rift basalts. The top of these lavas defines basement, with $\mathrm{K}-\mathrm{Ar}$ ages ranging from $135 \mathrm{Ma}$ and clustering around 
$120 \mathrm{Ma}$ (Fodor et al., 1983; Mizusaki, 1986). The main pulse of stretching and the full development of the hinge line along the East Brazil margin occurred at the same general time during the Buracica-Jiquiá stages (Syn-Rift III).

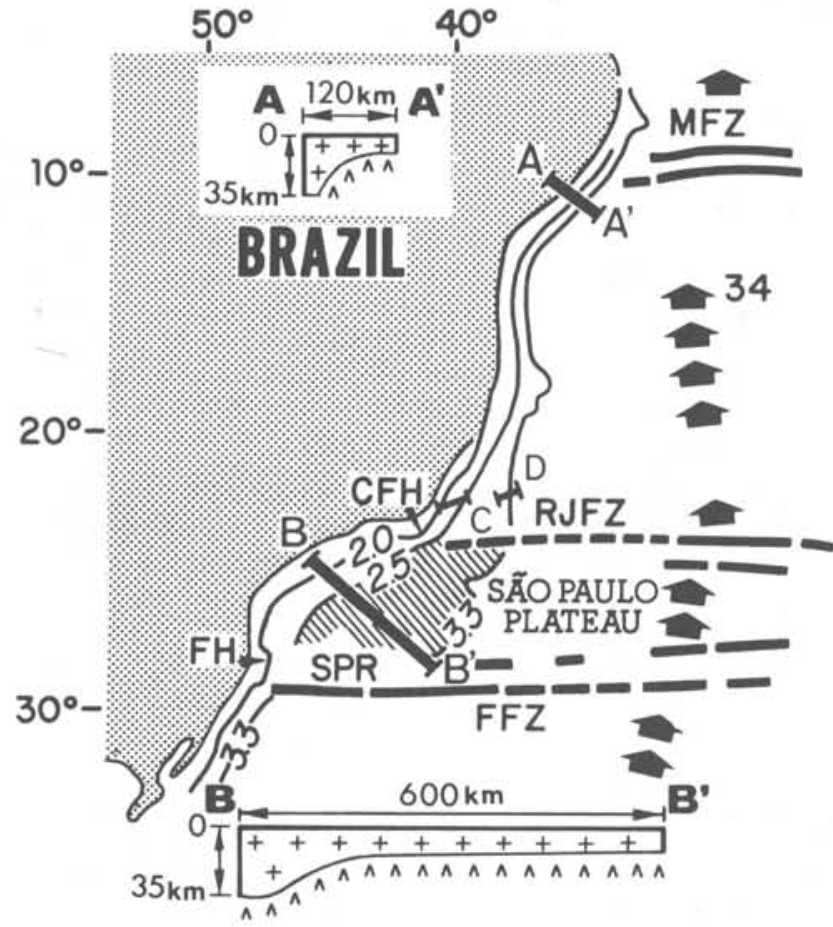

Figure 5: Simplified tectonic elements of the East Brazilian margin, showing contours of equal extension factor $B$ (see text for explanation). Sections $A-A$ ' and $B-B^{\prime}$ illustrate variations in the degree of crustal stretching-thinning. São Paulo Plateau (hachured); FH (Florianópolis High); CFH (Cabo Frio High); SPR (São Paulo Ridge); FFZ (Florianópolis Fracture Zone); RJFZ (Rio de Janeiro Fracture Zone); MFZ (Maceio Fracture Zone). Fracture zones compiled by Asmus (1984).

A generalized unconformity, produced during the late Jiquiá-early Alagoas stages, marked the end of rifting. This unconformity separates the tilted and block-faulted rift sequence from the overlying post-rift sequence (Figs. 6 and 7 ). The unconformity is most conspicuous near the hinge zone, where factors such as thermal and flexural bulges could have contributed to its emplacement, and where limited tectonic subsidence enhanced the vulnerability of the rift sequence to baselevel changes. The angular nature of the unconformity, so prominent at this proximal site, generally becomes more subtle seawards.

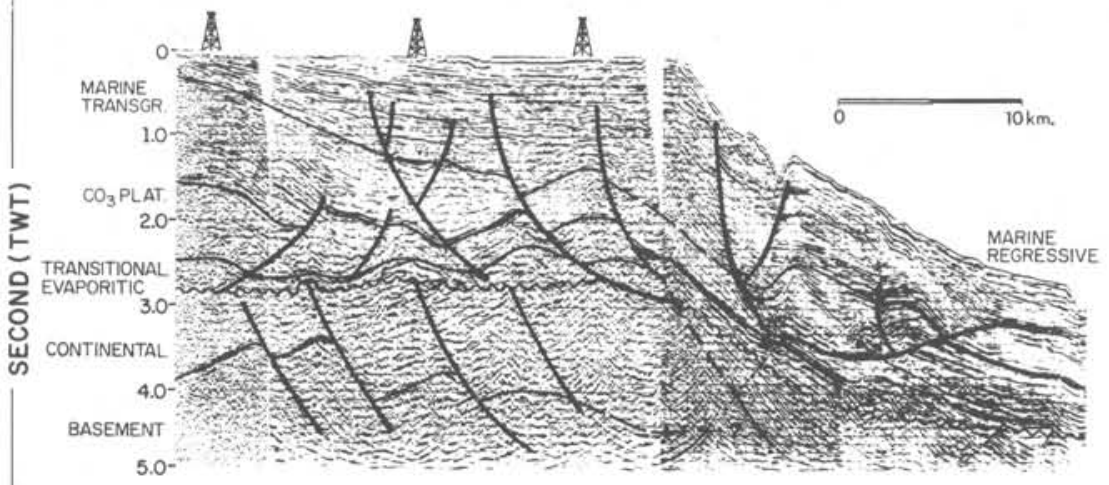

\section{Post-Rift Stage}

The general post-rift tectonic subsidence can be approximated, as in other passive margins, by an exponential decay curve characteristic of lithospheric cooling and contraction (Chang and Kowsmann, 1984, 1986). This subsidence produced the seaward tilting of the continental margin, which was infilled by a thick wedge of marine sediments. This wedge was intensively affected by listric faulting with a sole at the base of the Alagoas evaporite deposits (Fig. 6). The faults cross progressively younger strata seaward.

The faulting and consequent formation of rollover structures have been mainly attributed to salt flowage triggered by the margin tilt (Figueiredo et al., 1985). However, recent detailed studies in the Sergipe-Alagoas Basin (Lima, 1987) demonstrate on a large scale that basement, major unconformity and post-rift sediments are all gently warped to form large, single rollover structures, thus suggesting that massive brittle failure in the upper crust has occurred during the post-rift phase until very recent times.

The orientation of listric faults bounding these crustal detachment surfaces follows ancient Proterozoic thrust faults, indicating that the latter were reactivated by the post-rift tensile stresses. A sand model experiment and independent rock mechanics ealculations conducted by Lima (1987) suggest that shallow crustal failure will occur at very low angles of tilting (1-3 degrees). The large extent of the coastal flexural onlap, characteristic of the Tertiary section of the East Brazilian basins (Fig. 4), is mainly a consequence of the increasing flexural rigidity of the cooling lithosphere.

Tectonic movements in the form of coastal range uplift (up to $2000 \mathrm{~m}$ ) in Southeast Brazil (Serra do Mar, Fig. 1) and generalized plateau uplift of the hinterland (less than $1500 \mathrm{~m}$ ), dominated the Late Cretaceous-Tertiary scenario of the East Brazil margin. In parallel, late Senonian and Eocene volcanic activity occurred along the southeastern Brazil margin in the form of alkaline rocks on land and alkali-basalts offshore (Ponte and Asmus, 1978; Asmus and Porto, 1980; Almeida, 1983). Thermal anomalies induced by hot-spots and oceanic fracture zones have been called upon

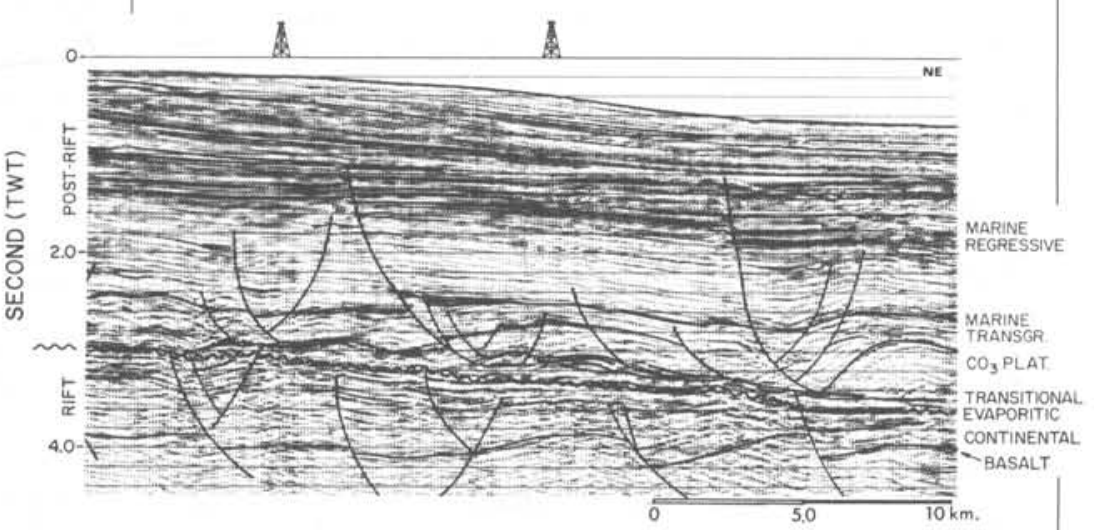

Figure 6: Seismic section from the Campos Basin showing the regional unconformity separating the Rift Stage Continental Megasequence from post-Rift Stage megasequences. Growth faults and associated roll-over structures due to halokinesis. Location on Figure 5 as section $C$.

Figure 7: Compressed regional seismic section across the Sergipe-Alagoas Basin showing stratigraphic megasequences, Rift and post-Rift structures separated by regional unconformity. Location in Figure 5 , section $A-A^{\prime}$. 
to explain these late stage magmatic events (Asmus in REMAC, 1978) and the uplift of the continent (Asmus and Ferrari in REMAC, 1978; Smith, 1982).

Isostatic adjustment of the basin and its edge has been invoked to explain the coastal uplift (Asmus and Ferrari, 1978; Macedo in REMAC, 1987). Flexural rebound due to the unloading associated with crustal failure (Gonealves, et al., 1979) appears to be an attractive mechanism to produce uplift. However, these concepts have only been proposed on a qualitative basis.

First motion studies of earthquakes indicate that the East Brazilian continental block is presently in a state of compression (Assumpção et al., 1985). This is compatible with a mid-ocean ridge push from the east and blocking of the South American plate in a subduction setting from the west. It is plausible that this state of stress has been operating since the initiation of sea-floor speading in the South Atlantic. This compressive stress field must have competed with the tensile stresses generated by the seaward tilting of the margin because both occurred during the post-rift stage. The interplay in time and space between these stress fields cannot as yet be distinguished.

\section{Continent-Ocean Boundary}

The continent-ocean crustal boundary to the south of the São Paulo Ridge is not as well established as on the conjugate, southwestern margin of Africa, where it lies along anomaly M4 (Austin and Uchupi, 1982). However, seismic refraction data (Leyden et al., 1971; Kowsmann et al., 1977) indicate that it should lie under the continental slope at least $700 \mathrm{~km}$ landward of its position north of the São Paulo Ridge (Fig. 5).

To the north of the São Paulo Ridge, geophysical evidence indicates that this crustal boundary lies along the salt scarp (Fig. 8) that delineates the seaward edge of the Alagoas evaporites (Kowsmann et al., 1982). This searp strikes roughly north-south and parallels the first identifiable oceanic magnetic anomaly ( $\mathrm{M} 34,84 \mathrm{Ma}$ ) in the region (Fig. 5). Sea-floor spreading is believed to have started here during the earliest Albian time, thus splitting the evaporite basin into two conjugate portions (Leyden et al., 1976). Assigning the end of the rifting event in the marginal basins as latest Jiquiá to earliest Alagoas and the onset of sea-floor spreading as earliest Albian poses a problem because there may be as much as $5 \mathrm{Ma}$ between them.

The region of stretched continental crust along the East Brazilian margin, bracketed by the hinge zone and the salt scarp, is roughly triangular in shape being widest in the south (São Paulo Plateau) and narrowest in the north. Thus, the integrated extension factors should be greater in the south than in the north, although measured extension factors within individual basins do not necessarily conform with this pattern. This configuration has considerable implications in the occurrence of rift stage volcanism as will be shown later.

\section{Lithospheric Thinning}

The megasequences characteristic of the East Brazilian margin follow a pattern that is predicted by various factors that in general control basin evolution along passive margins. Regional differences observed within these megasequences are modulated by local controls that can be integrated in a general context.

One of the striking contrasts in the rift stage stratigraphy here is the conspicuous presence of voleanies in the Syn-Rift II Sequence in the basins south of Espírito Santo and their absence in the basins to the north of it (Fig. 3). This distribution can be explained by the pattern of lithospheric extension of the East Brazilian margin to the north of the Florianópolis High-São Paulo Ridge, as deduced from tectonic subsidence studies using the Airy compensation. These show that the amount of extension varies from approximately 1008 ( $\beta=2.0$, see McKenzie, 1978 , for precise definition of this extension factor) just offshore of the hinge zone to 150 \& $(B=2.5)$ along the shelf edge and further to 230 o $(B=3.3)$ at the continent/ocean boundary (Fig. 5). Then contours, which are offset by the transfer zones adjacent to interbasinal highs and oceanic fracture zones, converge northwards toward Sergipe-Alagoas Basin, implying that the area of significant extension diminishes from south to north.

Foucher and others (1982) presented an elegant model in which the partial melting of asthenospheric mantle is a function of the degree of lithospheric extension or thinning. For a lithosphere $125 \mathrm{~km}$ thick, partial melting at the top of the asthenosphere $\left(1350^{\circ} \mathrm{C}\right)$ will begin as it rises adiabatically to approximately $60 \mathrm{~km}$ ( $20 \mathrm{kbar}$ ). This implies that partial melting should occur when the lithosphere is thinned by more than $50 \%(\beta>2.0)$. Partial melting in amounts significant enough $(10 \%)$ to form oceanic crust will occur only when the lithosphere is stretched by a beta factor of 3 to 4 .

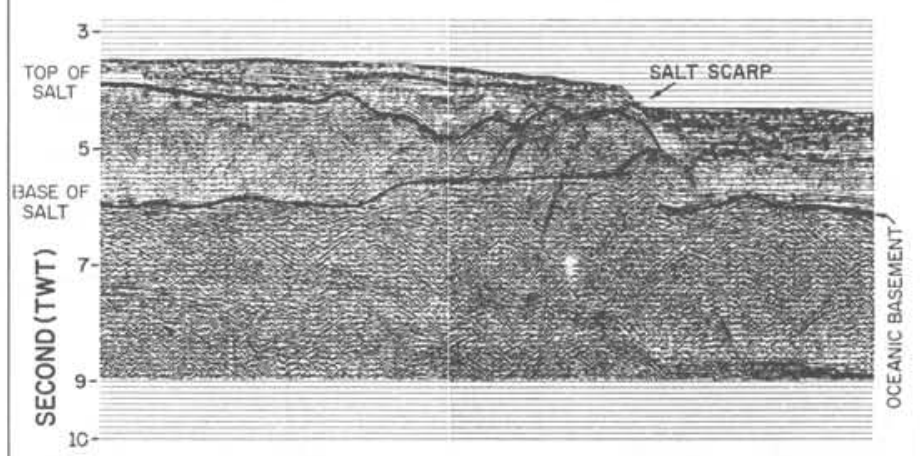

Figure 8: Seismic section off Campos Basin across the salt structure marking the offshore limit of Alagoas (Aptian) evaporite deposition in the Western South Atlantic. The scarp is believed to lie along the continent/ocean crustal boundary, with oceanic crust of Early Albian age lying to the right. Located on Figure 5 as section $D$.

The degree of lithospheric thinning not only influences the amount of partial melt produced but should also control the composition of magma generated (Ringwood, 1975). Partial melts of less than 108 should produce alkali-basalt; melts above this value should generate tholeiitic magmas. These compositional predictions are born out in the Campos and Santos basins where alkali-basalts predominate (Fodor and Vetter, 1984; Mizusaki, 1986). A more tholeiitic suite is expected to occur in the distal portions of these basins (São Paulo Plateau).

However, the degree of the lithospheric thinning does not alone explain why rift volcanism was so intense in the southeast Brazil margin and is virtually absent in the rift basins to the north of Espírito Santo, since beta values greater than 2.0 are present in all basins. The key difference here is the area affected by significant degree $(B>2.0)$ of stretching. The larger the area involved, the larger the volume of magma generated at the base of the lithosphere (Chang and Kowsmann, 1984), and large quantities of molten material will obviously be more successful in eventually reaching the surface of the crust than will small quantities. The area of significant stretehing is much larger in the Santos and Campos basins where volcanism occurred, than it is, for example, in Sergipe-Alagoas where volcanics are absent (Fig. 5).

Lithospheric stretching during the rift stage did not occur smoothly, but rather in distinet pulses, which greatly influenced facies distribution. For instance in the SergipeAlagoas Basin where rift stratigraphy is best recorded, 
minimum estimates point to a three-fold increase in sedimentation rate during the Jiquiá Stage when compared to the earlier stages of the rifting.

The Evaporitic Basin and the Carbonate Platform

The great South Atlantic evaporitic basin, so characteristic of the Alagoas Stage, was conditioned by a warm and dry climate, already prevalent during rift stage and induced by a low continental pressure cell (Parrish and Curtis, 1982). It was also a result of the continental configuration that allowed the influx of seawater into a silled elongated basin, from an established ocean to the south (Leyden et al., 1976, Arthur and Schlanger, 1979). The restriction was formed by the São Paulo-Walvis Ridge pair and was enhanced by a natural step occurring between the stretched continental crust to the north and oceanic crust to the south.

The composition of the evaporites around the South Atlantic ranges from highly soluble magnesian and potash chlorides to halite and anhydrite (Szatmari et al., 1979; de Ruiter, 1979). A shallow-water origin for the highly soluble salts is invoked by these authors. However, the origin of the massive halite deposits so prominent on the São Paulo Plateau and conjugate equivalent is not so clear (Leyden, 1976). Nevertheless, the carbonate platform megasequence that followed spanning the entire continental margin was established under shallow neritic conditions. Thus most of the offshore halite is believed to have accumulated under shallow-water conditions.

The progressive widening of the South Atlantic proto-ocean during the Albian developed geochemical conditions that permitted carbonate platform-forming biota to proliferate (Fig. 3). Microfacies and paleontological studies in the Brazilian marginal basins have shown that carbonate platform sedimentation occurred under arid and shallow, neritic conditions (Dias-Brito, 1982, 1987; Koutsoukos and DiasBrito, 1987, Azevedo et al., 1987; Spadini et al., in press).

The scarcity and low diversity of the biota, the light colour of the carbonates and the bioturbation were used by DiasBrito $(1982,1987)$ to conclude that hypersalinity was the main factor in determining the chemical environment. The high concentration of ${ }^{13} \mathrm{C}$ (delta ${ }^{13} \mathrm{C}=3-4$ o on the PDB standard, according to Spadini et al., in press) corroborates the hypersalinity.

The climate during the carbonate platform deposition was warm and dry (Dias-Brito, 1982). This conclusion, based upon petrographic evidence, agrees with that advocated by Lima (1983) and Vakrameev (1984) who respectively studied the flora of Brazil and of tropical A frica and South America during the Early Cretaceous.

\section{The Albian Drowning Event}

The shallow carbonate platform deposition along the margin was terminated rather abruptly by a drowning event that occurred sometime during middle to late Albian. In the Campos Basin the lithological record of this event consists of a level rich in glauconite pellets and phosphorite within a calcilutite unit (Fig. 9). This marker bed, which is easily identified by a gamma-ray peak, represents a hardground indicative of non-deposition and signals an increase in paleodepth. This sudden rise in sea level has been estimated at over $50 \mathrm{~m}$ for the entire continental margin of Brazil, based on benthic foraminifers (Koutsoukos and Dias-Brito, 1987).

This drowning event was marked enough to diminish carbonate production to the point where platform accretion was unable to accompany the first-order eustatic sea-level rise that culminated in the Late Cretaceous. This event is also well documented in the sedimentary section of the Malvinas/Falkland Plateau (Basov and Krasheninnikov, 1983). If this regional event proves to be of global significance, it may be responsible for the worldwide demise of carbonate platforms reported by Schlager (1981).

\section{The Cenomanian Climate Change}

The transition from calcilutites to shales and marls in the late Albian and Cenomanian is conspicuously reflected in well logs. A significant change from dry to humid climate during the Cenomanian has been documented by Lima (1983) and Vakrameev (1984). It coincides with the establishment of anoxic conditions along the Brazilian margin (Dias-Brito, 1982; Arai, in press) and the South Atlantic (Arthur and Schlanger, 1979; Herbin et al., 1987). The climatic change was probably due to the development of a sub-tropical high pressure cell over the enlarged South Atlantic watermass (Parrish and Curtis, 1982).

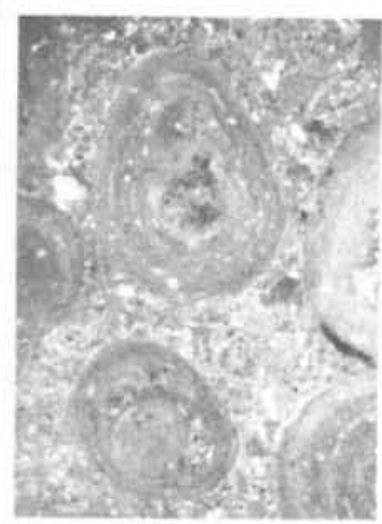

A

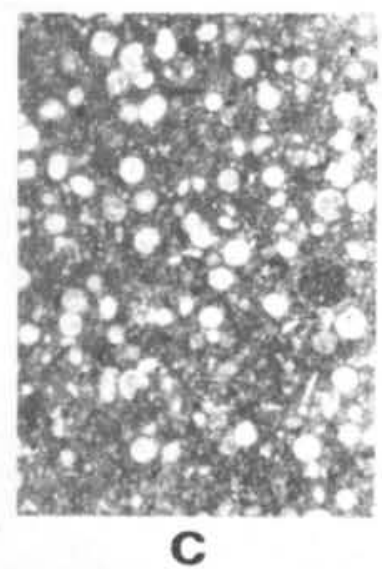

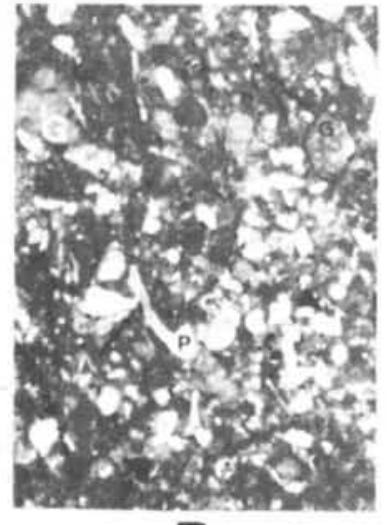

B

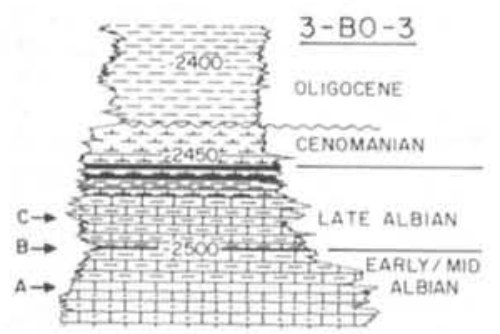

Figure 9: Detail of well log showing abrupt passage from shallow water limestones (Photo $A$, oncoliths) to deeper water limestones (Photo C, calcisphere-rich calcilutite) and marls. Gamma-ray peak coincides with the hardground rich in glauconite pellets $(G)$ and phosphorite ( $P$ - photo $B)$.

The combined tectonic subsidence (Fig. 10) became more evident after the end of the carbonate platform sedimentation. Basin starvation in conjunction with enhanced continental runoff due to a more humid climate led to the deposition of transgressive shaly units.

\section{Transgression to Regression}

The change from a transgressive to a regressive style of marine deposition is one of the most striking features of the stratigraphy of the East Brazilian marginal basins. It is marked by the change from a generally bathyal marine onlap sequence to a shallowing upward offlapping wedge, whose landward edge consists of an ever-expanding coastal plain. 
This transition, however, is not synchronous in all basins (Fig. 2). In the Santos Basin it occurred very early, in the late Turonian (Pereira et al., 1986), but in the Campos Basin it took place later, during the early Paleocene (Dias-Brito and Azevedo, 1986). In the Sergipe-Alagoas Basin, this transition is placed very late in the Eocene.

The ultimate development of the marine regressive sequence is easy to explain, in terms of tectonic subsidence and sea level. The timing of initiation of this sequence, variable from basin to basin, involves another component, namely the rate of local sediment supply. For basins at least $135 \mathrm{Ma}$ old, such as the Brazilian marginal basins, thermal subsidence became almost negligible from the beginning of the Tertiary onwards.

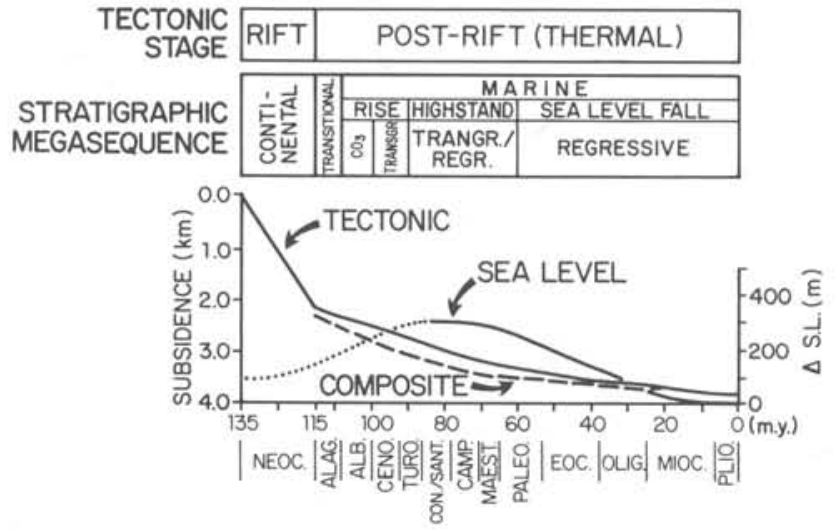

Figure 10: Composite subsidence curve and its relationship to the stratigraphic megasequences Curve was constructed by combining first order sealevel and tectonic subsidence curves. Sea-level curve based on Vail and others (1977, dotted) and Pitman (1978).

In contrast, the first order sea-level curves, as constructed by Vail and others (1977), Pitman (1978), and Hallam (1984) show a conspicuous overall global sea-level drop throughout the Cenozoic, although the exact magnitude of this drop is still under debate. Therefore, the resultant rate of change of the composite subsidence curve (Fig. 10) is negligible. This implies that almost any sediment infill in the basin will necessarily have to prograde into deeper waters, in order to keep below base level. In this way, the marine regressive sequence is developed. Regression, however, can start even before the composite subsidence curve is reduced to a negligible rate. This will occur whenever the rate of sediment supply overcomes the rate of the composite subsidence.
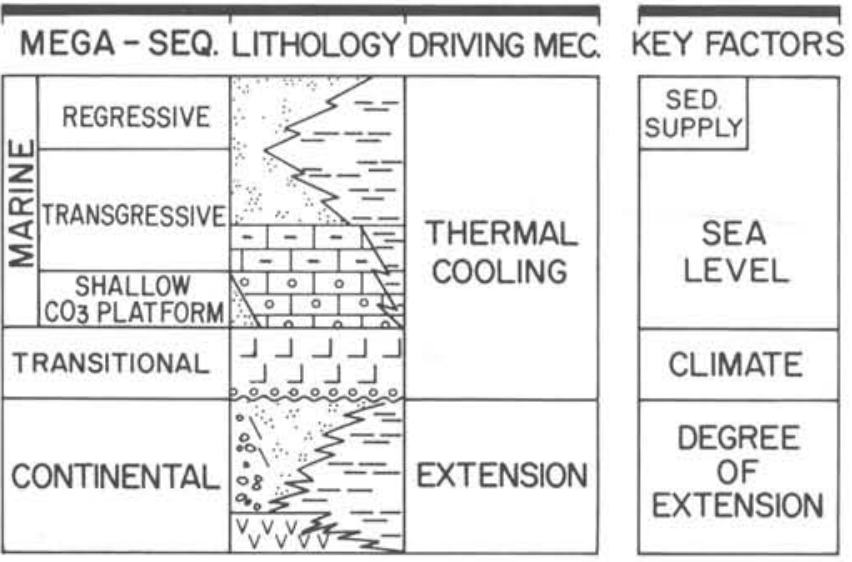

Figure 11: Key factors active in the development of the stratigraphic megasequences of the East Brazilian marginal basins.
The northward decrease in the age of the initiation of the marine regressive sequence can be explained by the location of the coastal range, Serra do Mar. This is closest to the Santos Basin (Fig. 1) to which it supplied large volumes of coarse clastic sediments (Santos Formation). The more distant Campos Basin, on the other hand, received a relatively smaller volume of more fine-grained clastics. Serra do Mar never contributed any sediment to the basins north of Espírito Santo.

\section{Summary}

The key factors in the development of the stratigraphic megasequences of the East Brazil marginal basins are summarized in Figure 11. The importance attributed to a single factor in any one stage is, of course, an over-simplification, and many others were no doubt active. However, the volcanic infill of the basins is indeed controlled by essentially one factor - lithospheric extension.

\section{Acknowledgements}

An early version of this paper benefited from the contribution of Laercio G.F. Aranha. The authors wish to thank Dimas Dias-Brito and Adali Spadini for helpful discussions regarding carbonate platform sedimentation. Thanks are due to Jorge C. Della Favera and Giuseppe Baccocoli for their constructive comments on the manuseript.

Dr. H.K. Chang is Chief of the Geology Section of the Petrobrás Research and Development Center (Cidade Universitaria, Rio de Janeiro, 21910, Brazil). He is currently working on simulation models of basin evolution.

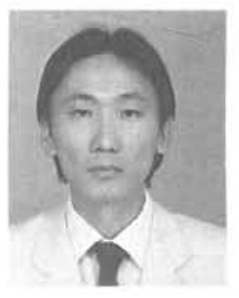

R.O. Kowsmann is also based at the Petrobrás Research and Development Center in $\mathrm{R}$ io de Janeiro, where he works in marine geology and basin studies.

Dr. A.M.F. de Figueiredo is at the Petrobras Exploration Department (Av. Chile, 65, Rio de Janeiro 20031). He is Division Manager for the southern Brazil margin and has coordinated the work of basin analysis groups for many parts of the coastal region.
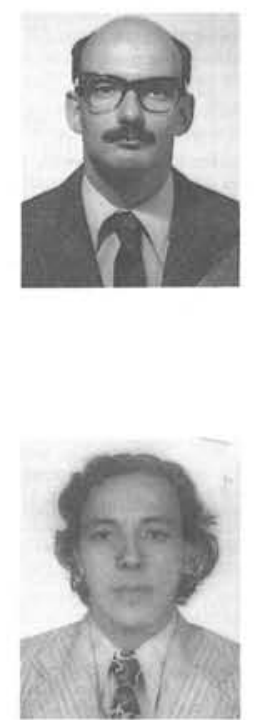


\section{References}

Almeida, F.F.M. de, 1983. Relaçỏes tectônicas das rochas alcalinas mesozóicas da regiffo meridional da plataforma sul-americana, Revista Brasileira de Geociências, v. 13, no. 3, p. 139-158.

Arai, M., in press Geochemical reconnaissance of Mid-Cretaceous anoxie event in the Santos Basin, Brazil. Revista Brasileira de Geociêneias.

Arthur, M.A. and Schlanger, S.O., 1979. Cretaceous oceanic anoxic events as causal factors in the development of reef-reservoired giant oil fields. American Association of Petroleum Geologists Bulletin, v. 63 , no. 6, p. $870-885$.

Asmus, H.E., 1984. Geologia da margem continental brasileira. in: Schobbenhaus, G. (coord.), Geologia do Brasil, Texto explicativo do Mapa Geológico do Brasil e da área oceâniea adjacente incluindo depósitos minerais escala $1: 2,500,000$. DNPM, p. 443-472.

Asmus, H.E, and Baisch, P.R., 1983. Geological evolution of the Brazilian continental margin. Episodes, v. 1983, no. 4, p. 3-9.

Asmus, H.E. and Ponte, F.C., 1973. The Brazilian marginal basins. In: Nairn, A.E.M. and Stehli, F.G. (eds.), The Ocean Basins and Margins, v. 1 - The South Atlantic. Plenum. Press New York, p, 87-133.

Asmus, H.F.. and Porto, R., 1972. Classificasão das bacias sedimentares brasileiras segundo tectônica de

Asmus, H.E. and Porto, R., 1980. Diferencas nos estagios iniciais da evolução tectònica da

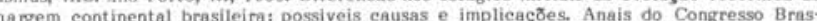
hleiro de Geologia 31, Camboriu, v. I, p. 225-239.

Assumpgão, M., Suarez, G. and Veloso, J.A., 1985. Fault plane solutions of intraplate earthquakes in Brazilt some constraints on the regional stress field. Tectonophysics, v. 113 no. $3-4$, p. $283-293$

Austin, J.A. and Uehupi, E., 1982. Continental - oceanic crustal transition off Southwest Africe, American Associntion of Petroleum Geologists Bulletin, v, 66, no, 9, p. 1328-1347, Azevedo, R.L., Gomide, J. and Viviers, M.C., 1987. Geohistória da Bacia de Campos Brasil, do Albiano ao Maestrichtiano. Revista Brasileira de Geociências, v. 17, p. 139-146. Basov, I.A. and Krasheninnikov, v.A., 1983. Benthonic foraminifers in Mesozoic and Cenozoic sediments of the Southwestern Atlantic as an indicators of paleoenvironment. In Initial Reports of the Deep sea Drilling Project, y. 71, part 2. U.S. Government Printing office, Washington, D.C., p. 739-787.

Bertani, R.T. and Carozzi, A.V., 1984. Mierofacies, depositional models and dingenesis of Lagoa Feia Formation (Lower Cretaceous), Campos Basin, offshore Brazil. Serie Ciência, Téenica e Petroleo, Petrobrás/CEN PES/SINTEP, v. 14, $104 \mathrm{p}$.

Bullard, E.C., Everett, J.E. and Smith, A.G., 1965. The fit of the eontinents around the Atlantic. In: Symposium on Continental Drif.
Society of London, v. $258 \mathrm{~A}$, no. $1088, \mathrm{p}, 41-51$.

Cande, S.C. and Rabinowitz, P.D., 1978 . Mesozoic seafloor spreading bordering conjugate continental margins of Angola and Brazil. Tenth Annual Ocean Technology Conference, v. 2, p. 1869-1876.

Castro, A.C., 1987. The Northeastern Brazil and Gabon basins: a double rifting system associated with multiple erustal detachment surfaces. Tectonies, v. 6, no. 6, p. 727-738.

Chang, H.K. and Kowsmann, R.O., 1984. Subsidencia térmica e espessura crustal da Bacin de Santos, Anais do Congresso Brasileiro de Geologia, 33, Rio de Janeiro, v. 4, p. 16021614.

Chang, H.K. and Kowsmann, R.O., 1986. Espessura crustal da Bacia de Sergipe-Alagoas Anais do Congresso Brasileiro de Geologia, 34, Goiania, v. 1, p. 110-121.

Cordani, U.G., Brito Neves, B.B., Fuck, R., Porto, R., Thomaz Filho, A. and Cunha, F.M.B. 1984. Estudo preliminar de integraş̃o do Pre-cambriano com os eventos tectónicos das SINTEP, v. 15, 70p.

Curie, D., 1984. Overture de I'Atlantique Sud et discontinuites intra-plaques: une nouvelle analyse. These de Doctorat de 3eme Cycle, Universitè de Bretagne Occidentale, 192. de Ruiter, P.A., 1979. The Gabon and Congo basins salt deposits. Economic Geology, v. 74, no. 2 , p. $419-431$.

Dias-Brito, D., 1982. Evolução paleoecológica da Bacia de Campos durante a deposição dos calcilutitos, margas e folhelhos da Formacĩo Macae (Albiano e Cenomaniano?). Boletion Técnico da Petrobrás, $y, 25$, no, 2, p. 84-97.

Dias-Brito, D., 1987. A Bacia de Campos no Mesocretaceo: uma contribuį̣ão a paleoceanografia do Atlantico Sul primitivo. Revista Brasileira de Geociências, v. 17, p. 162-167.

Dias-Brito, D. and Azevedo, R.L., I 986. As sequeneias deposicionais marinhas da Bacia de Campos sob a ótica paleoecológica. Anais do Congresso Brasileiro de Geologia, 34, Goiania, v. 1, p. 38-49.

Estrella, G.O., 1972. O estagio rift nas bacias marginais do Leste Brasileiro. Anais do Congresso Brasileiro de Geologia, 26, Belem, v. 3, p. 29-34.

Figueiredo, A.M.F., 1981. Depositional systems in the Lower Cretaceous Morro do Chaves and Coqueiro Seco formations and their reiationship to petroleum accumulations: middle $302 \mathrm{p}$.

Figueiredo, A.M.F., Pereira, M.J., Mohriak, W.U., Gaglianone, P.C. and Trindade, L.A., 1985. Salt tectonies and oil accumulations in Campos Basin, offshore Brazil. American Association of Petroleum Geologists Bulletin, v. 69, no. 2, p. 255, abstract.

Fodor, R.V., MeKee, E.H. and Asmus, H.E., 1983. K-Ar ages and the opening of the South Atlantic Ocean: basaltic rock from the Brazilian mangin. Marine Geology, v. 54, no. 1-2, p. M1-M8.

Fodor, R.V. and Vetter, S.K., 1984. Rift-zone magmatism: petrology of basaltic rocks transitional from CFB to MORB, Southeastern Brazil margin. Contribution Mineralogy and Petrology, v. 88, no. 4, p. 307-321.

Fontana, R.L., 1987. Desenvolvimento termomecanico da Bacia de Pelotas e a parte sul da plataforma de Florianópolis, Tese de mestrado, Universidade Federal de Ouro Preto, $128 \mathrm{p}$

Foucher, J.P., Le Pichon, $X$ and Sibuet, J.C., 1982. The ocean-continent transition in the uniform lithospheric stretching model: role of partial melting in the mantle. Philosophical uniform lithospheric stretehing model: role of partial melting in the miand
Transactions of the Royal Society of London, $v .305$, no. $1489, \mathrm{p} .27-43$.

Gonçalves, A., Oliveira, M.A. and Motta, S.O., 1979. Geologia da Bacia de Pelotas e Plataforma de Florianópolis. Boletim Téenieo da Petrobrás, v. 22, p. 157-174.

Hallam, A., 1984. Pre-Quaternary sea-level changes. Annual Review Earth and Planetary Seience, $v, 12, p, 205-243$

Herbin, J., Muller, C., de Graciansky, P.C., Jaequin, T., Magniez-Jannin, F. and Unternehr, P., 1987. Cretaceous anoxic events in the South Atlantic. Revista Brasileira de Geociencias, v. 17, p. 92-99.
Koutsoukos, E.A. and Dias-Brito, D., 1987. Paleobatimetria da maryem continental do Brasil durante o Albiano. Revista Brasileira de Geociências, v. 17, p. 86-9i.

Kowsmann, R.O., Leyden, R. and Francisconi, O., 1977. Marine seismic investigations, Southern Brazs.

Kowsmann, R.O., Costa, M.P.A., Boa Hora, M.P., Almeida, H.P. and Guimaraes, P.P., 1982. Geologia estrutural do Plato de São Paulo. Anais do Congresso Brasileiro de Geologia, 32 , Salvador, v. 4, p. 1558-1569.

Lana, M, and Milani, E.J., 1986. A microplaca do nordeste brasileiro - um elemento dinaGoiania, $x, 3$, D. $1131-1144$.

Le Fournier, J., Chorowicz, J. Thouin, C., Balzer, F., Chenet, P.Y., et al., 1985. The take Tanganyika Basin: tectonie and sedimentary evolution Academie des Sciences, Comptes Rendus, Paris 2, v, 301, no. 14, D. 1053-1057.

Leyden, R., 1976. Salt distribution and erustal models for the Eastern Brazil mary in. Anais do Academia Brasileira de Ciências, v. 48 Suplemento, p. 159-168,

Leyden, R., Ludwig, W.J. and Ewing, M., 1971. Structure of the continental margin of Punta del Este, Uruguay and Rio de Janeiro, Brazil. American Association of Petroleum Geologists Bulletin, v. 55, p. 2161-2173.

Leyden, R., Asmus, H.E., Zembruscki, S.G. and Bryan, G., 1976. South Atlantic diapiric struetures. American Association of Petroleum Geologists Bulletin, v. 60, p. 196-212.

Lima, C.C., 1987. Estruturagão pos-rift da porgão sergipana da Bacia Sergipe-Alagoas: o papel do basculamento $e$ das descontinuidades do embasamento. Tese de mestrado, Universidade Federal de Ouro Preto, 378 .

Lima, V.R., 1983. Paleoclimatic reconstruction of the Brazilian Cretaceous based on palynological data. Revista Brasileira de Geocièncias, v. 13, p. 223-228.

Uacedo, J.M., 1987. Evoluģ̃̃o estrutural da Bacia de Santos e áreas continentais adjacentes. Tese de mestrado, Universidade Federai de Ouro Preto, 165 .

MeKenzie, D.P., 1978. Some remarks on the development of sedimentary basins. Earth and Planetary Science Letters, v. 40, no. 1, p. 25-32.

Milanovskv, A.A., 1972, Continental rift zones: their arrangement and development. Teetonophysies, v. 15, no. 1/2, p. 65-70.

Mizusaki, A.M.P.P., 1986. Rochas igneas basicas do Neocomiano da Bacia de Campos; Carateristicas e comportamento conno reservatório de hidrocarbonetos. Tese de mestrado, Universidade Federal do Rio de Janeiro, 104p.

Mohriak, W.U. and Dewey, J.F., 1987. Deep seismic reflectors in the Campos Basin, offshore Brazil. Geophysical Journal of the Royal Astronomical Society, v. 89, no. I, p. 133-

Ojeda, H.A., 1982. Structural framework, stratigraphy and evolution of Brazilian marginal basins. American Association of Petroleum Geologists Bulletin, v. 66, no. 6, p. 732-749.

Parrish, J.T. and Curtis, R.L., 1982. Atmospheric eireulation, upwelling and organic-rich rocks in the Mesozoic and Cenozoic eras Palaeogeography, Palaeoclimatology and Palaeoecology, v. 40, no. 1-3, p. 31-66.

Pereira, M.J., Barbosa, C.M., Agra, J., Gomes, J.B., Aranha, L.G.F., Saito, M., Ramos, M.A., Carvalho, M.D., Stamato, M. and Bagni, O., 1986. Estratigrafia da Bacia de Santos: analise das sequencias, sistemas deposicionais e revisão litoestratigrafica. Anuis do Congresso Brasileiro de Geologia, 34, Goiania, v. 1, p. 65-79.

Pitman, W.C., 1978. Relationship between eustacy and stratigraphic sequences of passive margins. Geological Society of America Bulletin, v. 89, no, 9, p. 1389-1403.

Ponte, F.C. and Asmus, H.E., 1978. Geological framework of the Brazilian continental margin. Geologische Rundschau, v. 67, no. 1, p. 201-235.

Ponte, F.C., Dauzacker, M.V. and Porto, R., 1978. Origem e acumulag̃ão de petróleo nas bacias sedimentares brasileiras. Anais do Congresso Brasileiro de Petróleo v. 2, I, Rio de Janeiro, p. 121-147.

Rabinowitz, P.D. and La Breeque, J., 1979. The Mesozoic South Atlantic Ocean and evolution of its continental margins. Journal of Geophysical Researeh, v. 84, no. B11, p. 59736002 .

Rehim, H.A.A.A., Mizusaki, A.M.P.P., Carvalho, M.D. and Monteiro, M., 1986. Talco e estivensita na Formação Lagoa Feia da Bacia de Campos - possiveis implicações no ambiente deposicional. Anais do Congresso Brasileiro de Geologia, 34, Goiania, v. 1, p. 416-425. REMAC, 1978. Aspectos estruturais da margem continental este e sudeste do Brasil. Petrobrás, v. 4, 88p.

Ringwood, A.E., 1975. Composition and Petrology of the Earth's Mantle. MeGraw-tlitl, New York, 618 .

Schlager, W., 1981. The paradox of drowned reefs and carbonate platforms, Geological Society of America Bulletin, v. 92, no. 4, p. 197-211.

Sleep, N.H., 1971. Thermal effeets of the formation of Atlantic eontinental margins by continental break up. Geophysical Journal of the Royal Astonomical Society, v. 24, no. 4 , p. $325-350$.

Smith, A.G., 1982, Late Cenozoic uplift of stable ecntin

S America. Nature, $\mathrm{x}, 296$, no, 5856, D. 400-404.

Spadini, A.R., Esteves, F.R., Dias-Brito, D., Azevedo, R.L. and Rodrigues, R., in press. The Macae Formation, Campos Basin, Brazil: its evolution in the context of the initial histor of the South Atlantic. Revista Brasileira de Geociéncias.

Szatmari, P., Carvalho, R.S. and Simoes, I.A., 1979. A comparison of evaporite facies in Siddle Cretaceous South Atlantic salt basins. Economic Geology, v. 74, p. 432-447.

Szatmari, P., Milani, E.J., Lana, M., Conceiçao, J.C. and Lobo, A.P., 1985. How South Atlantic rifting affects Brazilian oil reserves distribution, Oil and Gas Journal, v. 83, no. 2 p. $107-114$.

Ussami, N., Karner, G.D. and Bott, M.H.P., 1986. Crustal detachment during South Atlantis rifting and formation of Tucano-Gabon besin system. Nature, v. 332, no. 6080, p. 629-632.

Vail, P.R., Mitchum Jr., R.M. and Thompson II, S., 1977, Seismic stratigraphy and global changes of sea level. In: Payton, C.E. (ed.), Seismic stratigraphy applications to hydrocarbon exploration. American Association of Petroleum Geologists, Mernoir 26, p. 83-97. Vakrameev, V.A., 1984. The climate of the tropical belt of Africa and South America in the Lower Cretaceous. Doklody Akademii Nauk, SSSR, v. 274, no. 4, p. 894-897 (in Russian).

Vink, G., 1982. Continental rifting and the implications for plate tectonic reconstructions Journal of Geophysical Researeh, v, 87, no. B13, p. 10677-10688.

Wernicke, B., 1985. Uniform-sense normal simple shear of the continental lithosphere. Canadian Journal of Earth Science, v. 22, no. 1. p. 108-125. 